\title{
A new species of Protrellus Cobb, 1920 (Nematoda, Thelastomatidae) parasite of the field cockroach Blatella vaga Hebard, 1919 (Blattodea, Blattidae) from Catamarca, Argentina
}

\author{
Nora B. Camino ${ }^{1,2^{*}}$ and Cristina de Villalobos ${ }^{1,3}$ \\ ${ }^{1}$ Investigador CIC. Comisión de Investigaciones Científicas de la Provincia de Buenos Aires 526 e/10 y 11, La Plata; \\ ${ }^{2}$ Centro de Estudios Parasitológicos y de Vectores Calle 2 no 584, 1900 La Plata; \\ ${ }^{3}$ Facultad de Ciencias Naturales y Museo, UNLP, Argentina
}

\begin{abstract}
A new species of the genus Protrellus, P. blatta sp. nov. parasitizing a field cockroach Blatella vaga Hebard, 1919, from El Tala river, Catamarca, Argentina, is described and illustrated. It is characterized by having the mouth opening circular, the buccal capsule with eight very small teeth, the nerve ring around oesophageal corpus, the excretory pore anterior to vulva, the vulva anterior to base of oesophagus, didelphic, the posterior ovary reflexed anterior to rectum, about one third of a body length from posterior end, the egg ellipsoidal, colourless, bearing a lateral cuticular crest, tail conical, with long filiform projection, the male with testis single, outstretched, one spicule, very small, short and straight, gubernaculums absent, the genital papillae arranged in three pairs of ventrolateral papillae, of which the first pair are close together and preanal position, two pairs postanal, tail conical and short, less than one twentieth of total body. A taxonomic key of Protrellus species is given.
\end{abstract}

\section{Keywords}

Nematoda, Protrellus, new species, cockroach

\section{Introduction}

The thelastomatids with the vulva located anterior to the base of the oesophagus form a group of five genera: Protrellus Cobb, 1920, parasite of cockroach from Australia, Madagascar, India, North and South America; Protrelloides Chitwood, 1932, parasitizing Blattodea from North America; Protrelleta Chitwood, 1932, in cockroach from North and South America; Napolitana Kloss, 1959, parasite of Blattodea from South America; Protrellatus Farooqui, 1970, in cockroach from India.

The genus Protrellus was proposed by Cobb 1920 for a nematode from an Australian cockroach, omitting the figures in his description. Then, in 1926 Schwenk added another species called P. galebi to this genus. Travassos, in 1929, transferred to this genus the species that Galeb 1878 had described as Oxyuris künckeli. Later, Chitwood 1932 regarded Protrellus with its type species $P$. aureus Cobb, as a genus and species inquirenda in the sub-family Protrelloidinae, and proposed a new genus Protrellina, to accommodate only all the other species which had been placed in Protrellus hitherto. The following year (1933) Chitwood remarked that Protrellina is a synonym of Protrellus, but from Cobb's poor and insufficient description made it impossible to include Protrellus in the familia Thelastomatidae. Basir 1956 reinstated the genus Protrellus, placing the genus Protrellina in synonymy with it. Kloss 1959, 1966 continued to recognise Protrellina but not Protrellus, and, in 1961, proposed Aglaopterixia for the species P. manni Chitwood, 1932. Adamson and van Waerebeke 1992 followed Basir's 1956 taxonomy and treated the genus Aglaopterixia Kloss, 1961 as a synonym of the genus Protrellus.

The fact that fifteen species of the genus Protrellus were collected from cockroaches (Adamson and van Waerebeke 1992; Shah et al. 2005, Table I) is important because cockroaches can carry human pathogens, such as Salmonella and Escherichia coli, which can result in human diseases, such as food poisoning or diarrhea, they also can transmit the hepatitis virus and have been known to spread dysentery and typhoid 
Table I. Reports of cockroaches as hosts of Protrellus species

\begin{tabular}{llll}
\hline \multicolumn{1}{c}{ Cockroaches species } & Protrellus species & Records & References \\
\hline Polyzostaria melanaria & P. aureus & Australia & See revisión Adamson and Van Waerebeke 1992 \\
Parcoblatta lata & P. aurifluss & USA & Basir 1956 \\
Elliptoblatta antennata & P. behorefi & Madagascar & Van Waerebeke 1969 \\
Periplaneta germanica & P. chauhani & India & Jagannath Rao 1980 \\
Celatoblatta vulgaris & P. dalei & New Zealand & Zervos 1987a \\
Drymaplaneta variegata & P. dixoni & New Zealand & Zervos 1987b \\
Eurycotes sp. & P. eurycotesi & Brazil & Skrjabin et al. 1966 \\
Ischnopteria & P. ischnopterae & Brazil & Zervos 1987a,b \\
Parasphaeria sp. & P. ituana & Brazil & Zervos1987a,b \\
Periplaneta americana & P. künckeli & Brazil & See revision Adamson and Van Waerebeke 1992 \\
Aglaopteryx diaphana & P. manni & Cuba & Chitwood 1933 \\
Phyllodromia humbertiana & P. phyllodromi & India & Skrjabin et al. 1966 \\
Gymnonyx grandidieri & P. rasolofi & Madagascar & Van Waerebeke 1969 \\
Periplaneta americana & P. shamimi & India & Manjur Shah et al. 2005 \\
Neostylopyga sexpustulata & P. travassosi & India & Jagannath Rao 1980 \\
Blatella vaga & P. blatta & Argentina & This report \\
\hline
\end{tabular}

fever (Brenner et al. 1987; Vythilingam et al. 1997). Products of cockroach infestations, including saliva, feces and cast skins, are sources of allergens and develop allergies that can trigger asthma in people, especially children (Eggleston et al. 1999; Sporik et al. 1999; Baumholtz et al. 2008). For all these reasons the cockroaches must be controlled, eliminating the use of insecticides that cause resistance in insects, and replacing them with natural parasites and pathogens. The field cockroach, Blattella vaga, prefers outdoor locations and is usually found in leaf litter, decaying vegetation, plant debris, and it also occurs under stones, clumps of earth, and similar objects. The field cockroach is believed to be an introduced species and was introduced from Asia into southern California, Arizona, New Mexico, and Texas. It is not repelled by light and can often be seen during the day.

In this investigation we report another species of the genus Protrellus, called P. blatta sp. nov. parasitizing a field cockroach Blatella vaga Hebard, 1919, and we cite for the first time this genus for Argentina. A taxonomic key of Protrellus species is given.

\section{Materials and Methods}

Twenty nymphs of the field cockroach Blatella vaga Hebard, 1919 (Blattodea, Blattidae) were found in the river coast of El Tala river (S 28 $27^{\prime} 34,26^{\prime \prime}, \mathrm{W} 65^{\circ} 50^{\prime} 28,11^{\prime \prime}$ ), Catamarca province, Argentina. They were collected by hand during 2010 autumn and were put in individual paper containers. The insects were dissected in Petri dishes filled with distilled water under a stereoscope microscope. A transverse incision was made along the posterior end of the abdomen and the digestive tract was removed to obtain the parasites $(n=44)$. Thirty-four nematodes were killed by placing them in distilled water at $60^{\circ} \mathrm{C}$ for $2 \mathrm{~min}$. They were removed to $50 \%$ TAF solution in water for 48 hours then into pure TAF. All thirty-four specimens were used for drawings, photographed and measured with the aid of a lucida camera mounted on a Zeiss compound microscope. Measurements were made using an ocular micrometer and are given as the mean \pm standard deviation followed by the range in parentheses. All measurements are given in micrometres (Table II).

In order to develop a more complete description of characters, we carry out an ultrastructural analysis using a scanning electron microscope (SEM), which has proven a better assessment of cuticular detail and to clarify the status of the nematodes. The ten remaining specimens were fixed in a cold solution of $1.5 \%$ glutaraldehyde $/ 1.5 \%$ formaldehyde in $0.1 \mathrm{M}$ acidulate buffer ( $\mathrm{pH}$ 7.35) overnight, postfixed in cold aqueous solution of $1 \%$ osmium peroxide overnight. The nematodes were dehydrated in an increasing ethanol series, critically point-dried, mounted on bronze blocks and goldsputter coated and observed and photographed using a JEOL JSM 6360 LV.

Holotype and allotype specimens are deposited in the Invertebrate Department, Museo de Ciencias Naturales, La Plata, Argentina (MLP). Paratypes are deposited in the Centro de Estudios Parasitológicos y Vectores (CEPAVE), Nematoda collecction, La Plata Argentina.

\section{Results}

\section{Protrellus Cobb, 1920 \\ Protrellus blatta sp. nov.}

Description: Small nematodes. Female: cuticle annulated in all along the body. Mouth opening circular. Eight labio 
Table II. Morphometric data for Protrellus blatta sp. nov., measurements in $\mu \mathrm{m} \pm \mathrm{SD}$ (range)

\begin{tabular}{|c|c|c|}
\hline & $\begin{array}{c}\text { Females }(\mathbf{n}=\mathbf{2 7}) \\
\text { Mean } \pm \text { SD }(\text { range })\end{array}$ & $\begin{array}{c}\text { Males }(\mathbf{n}=\mathbf{2 0}) \\
\text { Mean } \pm \text { SD (range) }\end{array}$ \\
\hline Total length & $3,969 \pm 95.7(3680.3-4,860.4)$ & $992.25 \pm 221.8(770.6-124.3)$ \\
\hline Diameter of head at level of cephalic papillae & $32.48 \pm 2.42(30-35.2)$ & $12.35 \pm 0.72(11.2-13.8)$ \\
\hline Stoma length & $9.28 \pm 2.8(6.5-12)$ & $5.24 \pm 1.4(4.1-6.8)$ \\
\hline Stoma width & $8.12 \pm 1.6(6.5-9.8)$ & $4.32 \pm 1.1(3.1-5.5)$ \\
\hline Width of body at level of nerve ring & $72 \pm 4.13(66-78)$ & $19.5 \pm 2.6(16.5-22.6)$ \\
\hline Width of body at anus level & $132 \pm 15.5(116-150)$ & $56 \pm 9.8(47-66.2)$ \\
\hline Width of body at level of vulva & $122 \pm 20(100-150)$ & - \\
\hline Distance anterior end to nerve ring & $126 \pm 47.6(78-175)$ & $52 \pm 22.2(28.6-76.7)$ \\
\hline Oesophagus length & $369 \pm 24.4(340-400)$ & $146 \pm 22.6(122.8-170.4)$ \\
\hline Distance from anterior end to excretory pore & $144 \pm 28.3(110.5-174.8)$ & $73 \pm 25.4(46.7-99.8)$ \\
\hline Length and width of eggs & $\begin{array}{l}81.2 \pm 2.1(78.2-83.5) \\
\times 32.48 \pm 2.2(29.8-35.4)\end{array}$ & - \\
\hline Spicule length & 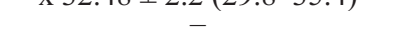 & $25 \pm 1.35(22.6-26.4)$ \\
\hline Spicule width & - & $2.52 \pm 0.6(1.92-3.25)$ \\
\hline Tail-appendage length & $216 \pm 12.5(210.6-235.6)$ & $51.22 \pm 12.8(38.2-65.4)$ \\
\hline
\end{tabular}

*V: (distance from anterior end to vulva/body length) x 100.

papillae (Fig. 8). Amphids small and pore shaped. Buccal capsule with eight very small teeth (Figs 2, 9). Oesophagus consisting of an anterior corpus, an isthmus, and posterior valvular bulb basal (Figs 1, 12). Nerve ring around oesophageal corpus. Intestine wide at its anterior end, glands between intestine and rectum distinct. Excretory pore anterior to vulva (Figs 1, 12). Vulva anterior to base of oesophagus (Figs 1, 12). Didelphic. Posterior ovary reflexed anterior to rectum, about one third of a body length from posterior end. Eggs ellipsoidal, colourless, bearing a lateral cuticular crest (Figs 5, 11). Tail conical, with long filiform projection (Figs 4, 10).

Male: much smaller than female, similar structure to the female. Cuticle not distinctly annulated. Eight labial papillae. Amphids very small, pore shaped. Oesophagus with a corpus, an isthmus and a basal bulb valvated (Fig. 3). Nerve ring at level of oesophageal corpus. Excretory pore at the base of the oesophagus. Testis single, outstretched. One spicule, very small, short and straight (Fig. 7). No gubernaculum. Genital papillae arranged in three pairs of ventrolateral papillae, of which the first pair are close together and preanal position, two pairs postanal (Fig. 6). Tail conical and short, less than one twentieth of total body length (Figs. 6, 7).

Type material: holotype and allotype (MLP). Paratypes.

Type locality: El Tala river (S 28 $27^{\prime} 34^{\prime \prime}$, W 65 $\left.50^{\prime} 28^{\prime \prime}\right)$, Catamarca province, Argentina.

Host: Nymphs of the cockroach Blatella vaga Hebard, 1919 (Blattodea, Blattidae).

Etymology: The name refers to the host.
Site of infection: Intestine, midgut.

Prevalence: $40 \%$.

Number of nematodes per nymph: 1-8.

\section{Remarks}

This is the first species of the genus Protrellus cited for Argentina, which is expanding its global distribution. Currently there are fifteen valid species of the genus Protrellus Cobb, 1920: P. aureus Coob, 1920; P. aurifluus (Chitwood, 1932) Basir, 1956; P. behorefi Van Waerebeke, 1969; P. chauhani Rao, 1980; P. dalei Zervos, 1987; P. dixoni Zervos, 1987; P. eurycotesi (Kloss, 1961) Skrjabin, Schikhobalova et Lagodovskaya, 1966; P. ischnopteria (Kloss, 1966) Zervos, 1987; P. ituana (Kloss, 1966) Zervos, 1987; P. künckeli (Galeb, 1877) Schwenk, 1926; P. manni (Chitwood, 1932) Chitwood, 1933; P. phyllodromi (Basir, 1942) Skrjabin, Schikhobalova et Lagodovskaya, 1966; P. rasolofi Van Waerebeke, 1969; $P$. shamimi Manjur Shah, Rizvi et Jairajpuri, 2005; and P. travassosi Jagannath Rao, 1980; which share the following characteristics: mouth opening circular or triangular, eight labio papillae, oesophagus with corpus, isthmus and basal bulb valvated, excretory anterior to vulva, vulva anterior to base of oesophagus, the eggs oval or ellipsoidal, colourless, yellow, yellow green, or yellow brown, often bearing a polar or lateral cuticular crest or boss, or lateral groove, tail of female conical to attenuate, male with a single spicule, two to five pairs of genital papillae, tail male subconical. 


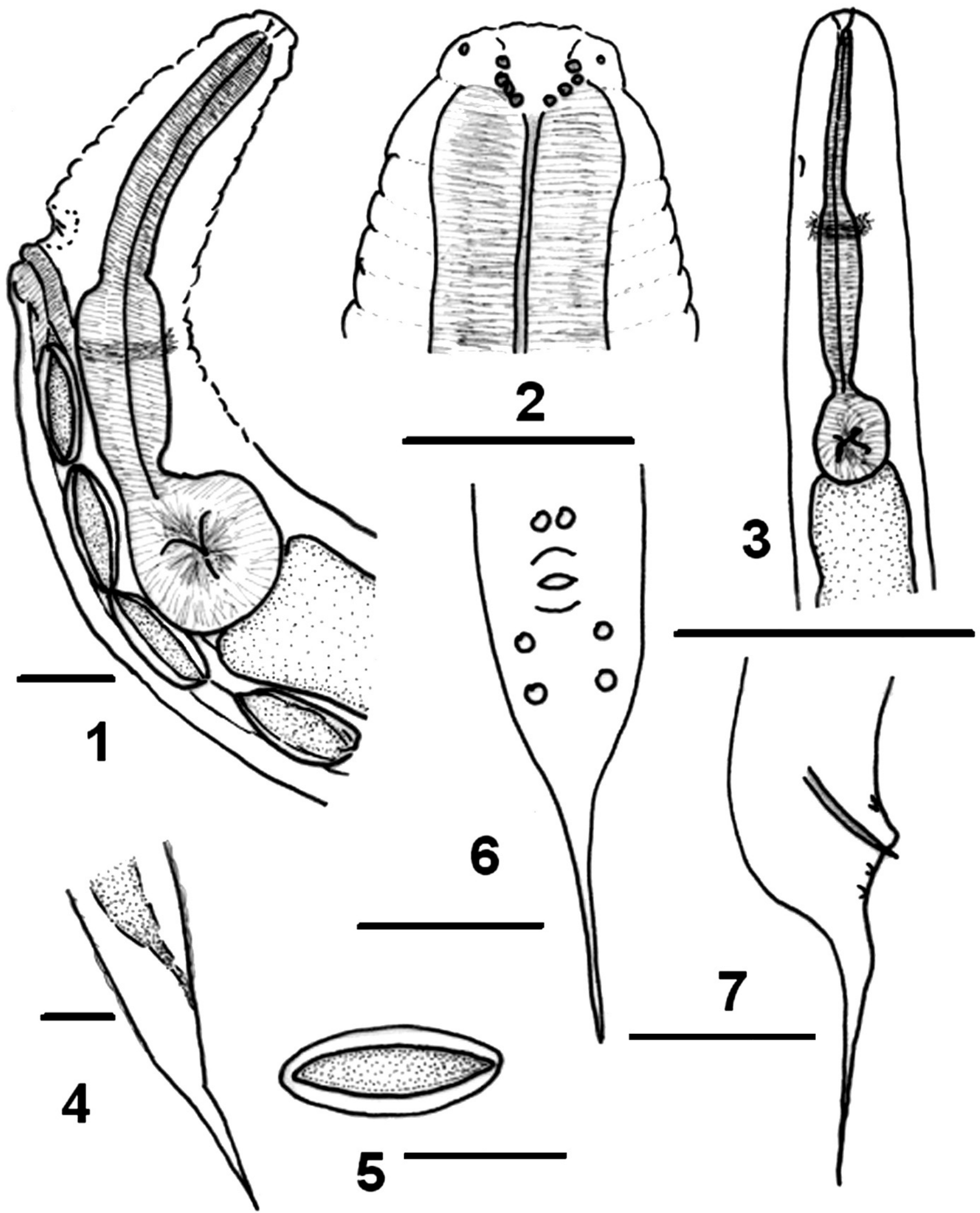

Figs 1-7. Protrellus blatta sp. nov. 1. Anterior end of female showing the oesophagus, eggs, vagina, excretory pore. 2. Stoma with teeth. 3. Anterior end of male. 4. Posterior end of female. 5. Egg. 6. Posterior end of male in ventral view. 7. Posterior end of male in lateral view. Bars $=1,2,3,5,6,7: 50 \mu \mathrm{m} ; 4: 100 \mu \mathrm{m}$ 

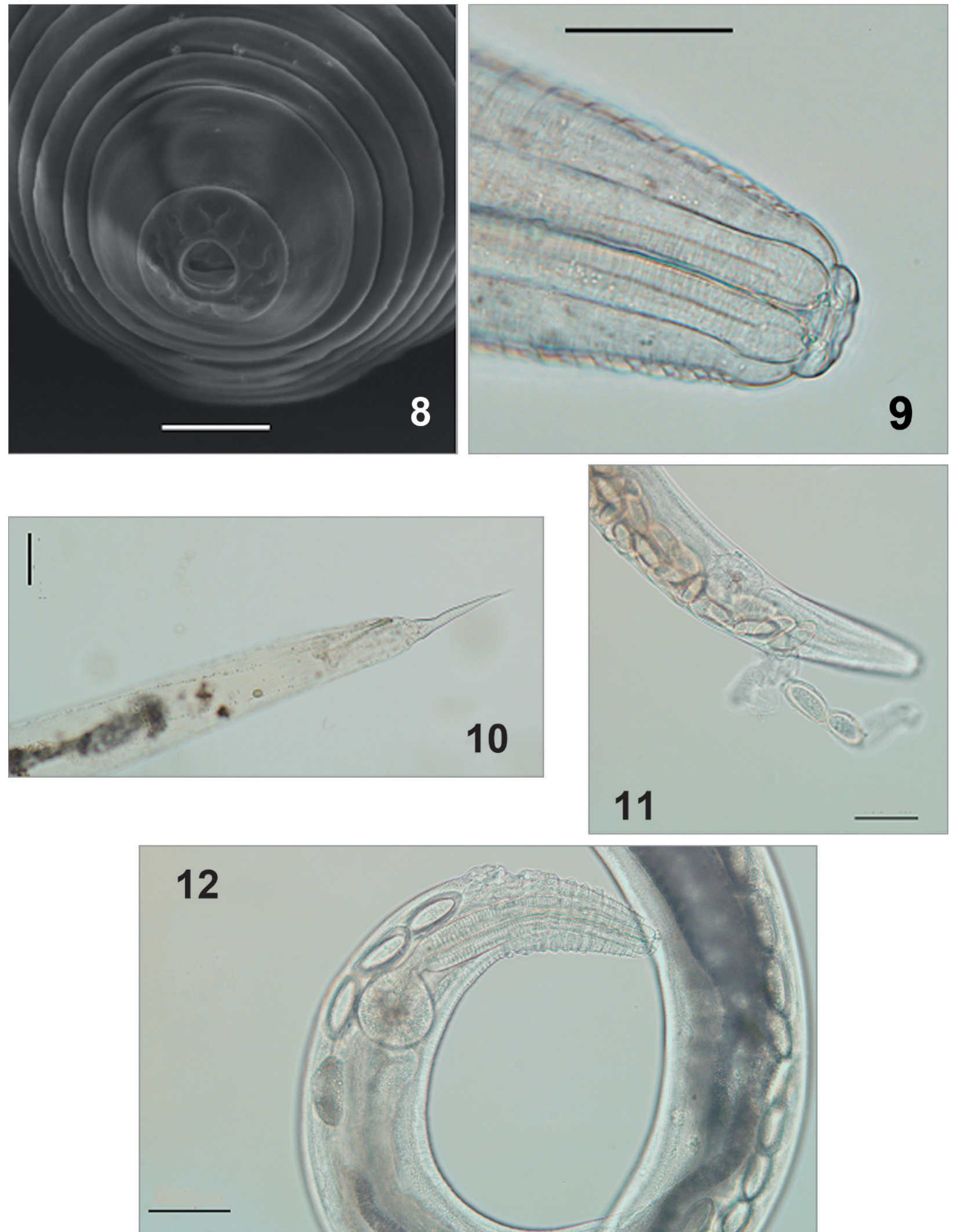

Figs 8-12. Protrellus blatta sp. nov. 8. Anterior end of female showing the cephalic papillae (SEM). 9. Stoma with teeth. 10. Posterior end of female. 11. Female oviposition. 12. Anterior end of female showing the oesophagus, eggs, vagina, excretory pore. Bars $=8: 10 \mu \mathrm{m} ; 9: 50$ $\mu \mathrm{m} ; 10,11,12: 100 \mu \mathrm{m}$ 
Protrellus aureus can be separated from our new species in having the female oesophagus short $(0.438 \mathrm{~mm}$ long $)$, tail acutely pointed, one spicule, linear and acute. P. aurifluus is distinguished by the position of the vulva near base of oesophagus, posterior ovary reflexed once in region of rectum, egg crest prominent, two pairs of caudal papillae in male which one pair is preanal and the other postanal. P. behorefi differs in the posterior uterus reflexed about one third of a body length from anterior end, tail conical. P. chauhani is separated by having larger eggs $(0.11$ to $0.14 \mathrm{~mm} \times 0.04$ to $0.05 \mathrm{~mm}$ ) and shorter male tail, one twentieth of total body length. $P$. dalei is characterized by the tail very short, conical, formed of two or three indistinct convex conoids of diminishing size, eggs oval, slightly broader at one end, shell thickened slightly at both ends, more so at pointed end, surface punctuate, with operculum. P. dixoni is different by having four pairs of caudal papillae in male, cuticular annulations broad and narrow anterior to vulva. P. eurycotesi can separate by the vulva is located in the posterior third of corpus, eggs ellipsoidal, laterally compressed, presenting a strongly developed and sclerotized protuberance, finely striated surface. P. ischnopteria differs by the position of the vulva which is about half way along oesophageal corpus, excretory pore not evident, posterior ovary reflexed twice anterior to rectum, egg crest reduced. P. ituana is distinguished by the posterior uterus reflexed about one sixth of a body length from posterior end, tail subulate, eggs oval with small spines on all surfaces, excretory pore without lip. P. künckeli is characterized by having the vulva in the region of oesophagus basal bulb. P. manni has the egg bearing a crest with cuticular bosses, female tail with medial constriction, oesophagus corpus bent before union with isthmus, vulva near posterior end of corpus, two ovaries. P. phyllodromi can be separated by the egg without crest but with two lateral grooves, and the female tail short not filiform. P. rasolofi with a cuticular fold tongue-shaped, ovary reflexed in the region of the rectum, tail long and filiform, a pair well development of preanal papillae, two pairs of postanal papillae which the first pair is reduced and the second one is located in the tail.

Protrellus shamimi is different by having five pairs of caudal papillae and the caudal appendage which is modified into a short filiform projection in male, and the tail in female is bluntly conical. P. travassosi differs in having the egg with a crest in the middle and absence of cuticular protuberances on it.

Protrellus blatta sp. nov. is characterized by having the mouth opening circular, the buccal capsule with eight very small teeth, the nerve ring around oesophageal corpus, the excretory pore anterior to vulva, the vulva anterior to base of oesophagus, didelphic, the posterior ovary reflexed anterior to rectum, about one third of a body length from posterior end, the egg ellipsoidal, colourless, bearing a lateral cuticular crest, tail conical, with long filiform projection, the male with testis single, outstretched, one spicule, very small, short and straight, gubernaculums absent, the genital papillae arranged in three pairs of ventrolateral papillae, of which the first pair are close together and preanal position, two pairs postanal, tail conical and short, less than one twentieth of total body. For all the above we consider Protrellus blatta sp. nov. has unique features that allow separate from other species of the genus.

Key to species in the genus Protrellus (modified Zervos 1987)

1. Female tail conical, with long filiform projection ............. 2

- Female tail short, no filiform projection .............................. 5

2. Female excretory pore without lip, posterior ovary reflexed anterior to rectum, about one third of a body length from posterior end, egg ovoid without crest or bosses ............. 10

- Female excretory pore with lip, posterior ovary reflexed at or posterior to rectum, egg ovoid without crest or bosses, ....... 3

3. Female cuticular annulations broad and narrow anterior to vulva, excretory pore with thin circular or oval lip, muscular ovijector, 4 pairs of genital papillae ............... P. dixoni

- Female cuticular annulations more or less uniform anterior to vulva, excretory pore covered by flap or not, no ovijector, 3 pairs of genital papillae ............................................. 4

4. Mouth subtriangular, excretory pore covered by a flap .................................................................... P. rasolofi

- Mouth rounded, excretory pore without any cover. P. blatta sp. nov.

5. Female: vulva in region of oesophageal basal bulb (n...P. künckeli - Female: vulva anterior to oesophageal basal bulb ............. 6

6. Excretory pore not evident, vulva not salient, with ovijector P. eurycotesi

- Excretory pore evident, vulva salient, with or without ovi-

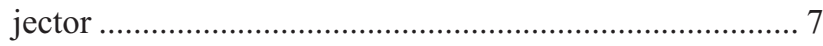

7. Female tail plainly conical ................................................... 8

- Female tail with small appendix or pronounced constric-

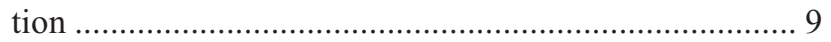

8. Female vulva about half way long oesophageal corpus, excretory pore not evident, posterior ovary reflexed twice anterior to rectum, egg crest reduced ........ P. ischnopterae - Female vulva near base of oesophageal corpus, ecretory pore evident, posterior ovary reflexed once in region of rectum, egg crest prominent . P. aurifluus

9. Female tail with medial constriction, oesophageal corpus bent before union with isthmus, vulva near posterior end of corpus, lateral crest of egg with cuticular bosses .... P. manni

- Female tail with short appendix, oesophageal corpus lineal, vulva about half way along corpus, lateral crest of egg without bosses 10 
10. Female: length of head to vulva $>270$, egg $>100$ long, without lateral groove .. 11

- Female: length of head to vulva $<230$, egg $<85$ long, with or without lateral groove 12

11. Female 6000 long, 100 wide, without ovijector, tail acutely pointed, mouth opening triangular, excretory pore without lip, male 610 long, spicule linear and acute ........ P. aureus

- Female 2980-4900 long, 130-310 wide, with ovijector, tail conical composed of diminishing conoids, mouth opening circular, excretory pore with lip, male 840-1148 long, spicule round proximally, wide medially, pointed distally, linear but not acute P. dalei

12. Female: vulva $6.5 \%$ of body length from anterior end, nerve ring $5.6 \%$ of body length from anterior end, tail plainly conical, egg with two lateral grooves

P. phyllodromi

- Female: vulva 3.2-5.5\% of body length from anterior end, nerve ring $2.2-4.3 \%$ of body length from anterior end, tail subulate or composed of diminishing convex conoids, egg without lateral grooves 13

13. Female: posterior uterus reflexed about one sixth of a body length from posterior end, tail subulate, excretory pore without lip, egg oval P. ituana

- Female: posterior uterus reflexed about one third of a body length from anterior end, tail not subulate, composed of diminishing convex conoids, excretory pore with lip, egg cresentrically ovoid P. behorefi

Acknowledgements. We would like to thank Mrs. Patricia Sarmiento from the Scanning Electron Microscopy Service (Museo de Ciencias Naturales, La Plata Argentina) for preparation of the material. Many thanks also to two anonymous reviewers for the constructive comments on the manuscript.

\section{References}

Adamson M.L., van Waerebeke D. 1992. Revision of the Thelastomatoidea, Oxyurida of invertebrate hosts. I. Thelastomatidae. Systematic Parasitology, 21, 21-63.

Basir M.A. 1942. Protrellina phyllodromi sp. nov., a new nematode parasite of the cockroach Phyllodromia humbertiana Sauss. Current Science (Bangalore), 11, 195-197.

Basir M.A. 1956. Oxyuroid parasites of arthropods. A monographic study. 1. Thelastomatidae 2. Oxyuridae. Zoologica (Stuttgart), $79 \mathrm{pp}$.

Baumholtz M.A., Parish L.C., Witkowski J.A., Nutting W.B. 2008. The medical importance of cockroaches. International Journal of Dermatology, 36, 90-96. DOI: 10.1046/j.13654362.1997.00077.

Brenner R.J., Koehler P., Patterson R.S. 1987. Health Implications of Cockroach Infestations. Infestations in Medicine, 4, 349 355

Chitwood B.G. 1932. A synopsis of nematodes parasitic in insects of the family Blattidae. Zeitschrift für ParasitenKunde, 5, 14-50.
Chitwood B.G. 1933. A revised classification of Nematoda. Journal of Parasitology, 20, 131.

Cobb N.A. 1920. One hundred new nemas (Type species of 100 new genera). Contribution to the Science of Nematology. Baltimore, Waverly Press, $343 \mathrm{pp}$

Eggleston P.A., Wood R.A., Rand C., Nixon W.J., Chen P.H., Lukk P. 1999. Removal of cockroach allergen from inner-city homes. Journal of Allergy and Clinical Immunology, 104, 842-846. DOI: 10.1016/S0091-6749(99)70296-4.

Farooqui M.N. 1970. Some known and new genera and species of the family Thelastomatidae Travassos, 1929. Rivista di Parassitologia, 31, 195-214.

Galeb O. 1877. Sur l'anatomie et les migrations des Oxyurides, parasites des insects du genera Blatta. Compte Rendu de l'Académie des Sciences, Paris, 85, 236-390.

Galeb O. 1878. Recherches sur les entozoaires des insects. Organization et développement des oxyuridées. Archives de Zoologie Experimentale et Generale, 7, 283-290.

Jagannath Rao V. 1980. Description of two new species of nematodes belonging to the genus Protrellus Cobb, 1920, from roaches with a key to the species of the genus and comments on allied genera. Proceedings of the Indian Academy of Parasitology, $1,57-65$.

Kloss G.R. 1959. Nematodes parasitos de baratas. Atas da Sociedade de Biologia do Rio de Janeiro, 3, 6-8.

Kloss G.R. 1961. Dois nematoides parasitos intestinais de especies selvagens de Blattaria. Papeis Avulsos do Departamento do Zoología (São Paulo), 14, 243-247.

Kloss G.R. 1966. Revisão dos nematóides de Blattaria do Brasil. Papeis Avulsos do Departamento do Zoologia, Sao Paulo, 18, 147-188

Shah M., Rizvi A.N., Jairajpuri D.S. 2005. Protrellus shamimi n. sp. (Protrelloidae: Thelastomatoidea) from the cockroach Periplaneta americana from Manipur, North-East India. Journal of Parasitic Diseases, 29, 47-52.

Schwenk J.M. 1926. Fauna parasitological dos blattideos do Brasil Sciencia Medica (Rio de Janeiro), 4, 491-504.

Skrjabin K.I., Schikhobalova N.P., Lagodovskaya A. 1966. Principles of nematology. (Ed. by K.I. Skrjabin). Vol. XV. Oxyurata of Arthropoda. Part 4. Izd. Nauka, Moscow, 538 pp.

Sporik R., Squillace S.P., Ingram J.M., Rakes G., Honsinger R.W., Platts-Mills T.A. 1999. Mite, cat, and cockroach exposure, allergen sensitization, and asthma in children: a case-control study of three schools. Thorax, 54, 675-80.

Travassos L. 1929. Contribuição preliminar a systematica dos nematodos dos arthropodos. Memorias do Instituto Oswaldo Cruz, 5, 19-25.

Van Waerebeke D. 1969. Quelques nematodes parasites de blattes a Madagascar. Annales de Parasitologie Humaine et Comparee, 44, 761-776.

Vythilingam I., Jeffery J., Oothuman P., Abdul Razak A.R., Sulaiman A. 1997. Cockroaches from urban human dwellings: isolation of bacterial pathogens and control. Southeast Asian Journal of Tropical Medicine and Public Health, 28, 218-22.

Zervos S. 1987a. Protrellus dalei n. sp. Blatticola barryi n. sp. and Suifunema mackenziei n. sp. thelastomatid nematodes from New Zealand cockroaches. New Zealand Journal of Zoology, 14, 239-250

Zervos S. 1987b. Protrellus dixoni n. sp. (Nematoda: Thelastomatidae) from cockroach Drymaplaneta variegata. New Zealand Journal of Zoology, 14, 251-256

(Accepted November 09, 2012) 